University of Nebraska - Lincoln

DigitalCommons@University of Nebraska - Lincoln

USDA National Wildlife Research Center - Staff Publications
U.S. Department of Agriculture: Animal and Plant Health Inspection Service

February 2001

\title{
Effects of sterilization on territory fidelity and maintenance, pair bonds, and survival rates of free-ranging coyotes
}

Cassity Bromley

Eric M. Gese

USDA/APHIS/WS National Wildlife Research Center, eric.gese@usu.edu

Follow this and additional works at: https://digitalcommons.unl.edu/icwdm_usdanwrc

Part of the Environmental Sciences Commons

Bromley, Cassity and Gese, Eric M., "Effects of sterilization on territory fidelity and maintenance, pair bonds, and survival rates of free-ranging coyotes" (2001). USDA National Wildlife Research Center - Staff Publications. 528.

https://digitalcommons.unl.edu/icwdm_usdanwrc/528

This Article is brought to you for free and open access by the U.S. Department of Agriculture: Animal and Plant Health Inspection Service at DigitalCommons@University of Nebraska - Lincoln. It has been accepted for inclusion in USDA National Wildlife Research Center - Staff Publications by an authorized administrator of DigitalCommons@University of Nebraska - Lincoln. 


\title{
Effects of sterilization on territory fidelity and maintenance, pair bonds, and survival rates of free-ranging coyotes
}

\author{
Cassity Bromley and Eric M. Gese
}

\begin{abstract}
Predation on sheep by coyotes (Canis latrans) is a longstanding problem for sheep producers. Current research suggests that surgical sterilization of coyotes could prove to be an effective method of reducing their depredation rates on domestic sheep by modifying their predatory behavior. However, for sterilization to be a viable management tool, the territorial and affiliative behaviors of pack members would need to remain in place. We tested whether surgically sterilized coyotes maintained pair bonds and territories in the same manner as intact coyotes. We also examined if territory fidelity and survival rates differed between sterile and intact coyotes. From June 1997 to April 2000, 10 males and 9 females were sham-operated and radio-collared, while 20 males and 6 females were surgically sterilized and radio-collared. We monitored members of 5 sterile and 4 intact packs during 1998, 6 sterile and 7 intact packs during 1999, and 4 sterile and 6 intact packs through the 2000 breeding season. Behaviorally, sterile packs appeared to be no different than intact packs. A half-weight association index showed that social dyads within sterile coyote packs were located together as frequently as dyads within intact packs. Simultaneous radiolocations of members of sterile packs showed that members of sterile packs were significantly closer to each other than would be expected from random locations. There was no difference in size or degree of overlap between territories of sterile and shamoperated coyote packs. Sterile coyotes had a higher annual survival rate than reproductive animals in 2 of the 3 years, and there was no difference in the level of territory fidelity. We concluded that surgical sterilization did not modify the territorial or affiliative behaviors of free-ranging coyotes, and therefore sterile coyotes could be used as a management tool to exclude other potential sheep-killing coyotes.
\end{abstract}

Résumé : La prédation opérée sur les moutons par les Coyotes (Canis latrans) est un problème de longue date pour les éleveurs de moutons. Des recherches récentes indiquent que la stérilisation chirurgicale des coyotes pourrait être une façon efficace de diminuer les taux de prédation exercée sur les moutons domestiques car elle modifie le comportement prédateur des coyotes. Cependant, pour que la stérilisation soit un outil de gestion efficace, il faudrait que les comportements territoriaux et les comportements d'affiliation restent les mêmes. Nous avons vérifié si les coyotes stérilisés par chirurgie sont capables de maintenir la fidélité à un territoire et les liens entre deux individus aussi bien que les coyotes témoins. Nous avons également vérifié si la fidélité au territoire et les taux de survie diffèrent chez les coyotes stérilisés et les coyotes intacts. De juin 1997 à avril 2000, nous avons procédé à des opérations simulées sur 10 mâles et 9 femelles et stérilisé vraiment 20 mâles et 6 femelles et nous avons muni tous ces animaux d'un collier émetteur. Nous avons suivi ainsi 5 meutes stériles et 4 intactes en 1998, 6 stériles et 7 intactes en 1999 et 4 stériles et 6 intactes pendant la saison de reproduction 2000. Le comportement des meutes stériles ne semblait pas différer de celui des meutes témoins. Un coefficient d'association (« half-weight association index ») a montré que les dyades sociales au sein des meutes stériles se retrouvaient ensemble aussi souvent que les dyades au sein des meutes intactes. Le repérage simultané par radio de membres des meutes stériles a permis de constater que les individus des meutes stériles se tiennent plus près les uns des autres que s'ils étaient répartis au hasard. Nous n'avons pas observé de différences dans la taille des territoires ou l'importance du recoupement entre les meutes stériles et les meutes qui n'ont subi que des opérations simulées. Le taux de survie annuel des coyotes stériles s'est révélé plus élevé que celui des coyotes reproducteurs au cours de 2 des 3 années de l'étude et les deux groupes avaient le même degré de fidélité au territoire. Nous concluons que la stérilisation par chirurgie ne modifie pas les comportements territoriaux ou les affiliations chez les coyotes en nature. Les coyotes stérilisés pourraient ainsi être utilisés en gestion pour assurer l'exclusion d'autres coyotes prédateurs de moutons.

[Traduit par la Rédaction]

Received June 22, 2000. Accepted November 8, 2000. Published on the NRC Research Press Web site on February $26,2001$.

C. Bromley. Department of Fisheries and Wildlife, Utah State University, Logan, UT 84322-5210, U.S.A.

E.M. Gese. ${ }^{1}$ National Wildlife Research Center, Department of Fisheries and Wildlife, Utah State University, Logan, UT 84322-5295, U.S.A.

${ }^{1}$ Corresponding author (e-mail: egese@cc.usu.edu). 


\section{Introduction}

People have been trying to prevent coyotes (Canis latrans) from killing domestic sheep for as long as sheep grazing and coyotes have coexisted. In Utah, ranchers reported the loss of 19000 lambs and sheep in 1997 (U.S. Department of Agriculture 1998), and losses to predators have been cited as a factor in ranchers leaving the industry (Gee et al. 1977). Till and Knowlton (1983) suggested that provisioning of pups may be a factor driving coyote predatory behavior. When both pups and adult coyotes were removed, predation on sheep declined by $98.8 \%$. When just pups were removed and adults were left in place, sheep losses declined by $91.6 \%$. In areas where no control was performed, losses declined by $4.2 \%$. Those authors hypothesized that sterilization might be even more effective because the sheep losses that occurred before pups were removed would be avoided. In addition, if sterilized coyotes maintain pair bonds and defend territories, other benefits would accrue: pairs defending a territory could exclude other potential sheep-killing coyotes, and these benefits could continue for several years, as long as the coyotes survived and pair bonds remained intact.

Sterilization has been discussed as a wildlife management tool (Garrott 1995) in many contexts, including control of rabies (Linhart and Enders 1964) and limiting the distribution and numbers of animals such as feral horses (Kirkpatrick et al. 1990), geese (Branta canadensis) (Converse and Kennelly 1994), deer (Odocoileus virginianus) (Matschke 1977; Plotka and Seal 1989), burros (Turner et al. 1996), and red foxes (Vulpes vulpes) (Linhart and Enders 1964; Oleyar and McGinnes 1974; Pech et al. 1997). However, the effect of sterilization on wild carnivore behavior has not been widely investigated (Asa 1995). Mech and Fritts (1993) reported that 5 vasectomized wolves (Canis lupus) maintained territories and pair bonds. Haight and Mech (1997) developed a model testing the use of vasectomy for wolf control. A study of red foxes in Australia showed that during the first year after they were surgically sterilized, females maintained home ranges similar in size to intact females, but overlap of home ranges was greater among sterile vixens (Saunders and McIlroy 1996). Dominance relationships, mortality rates, and behavior did not change, and compensatory reproduction apparently did not occur (Saunders and McIlroy 1996; Bubela 1999). Balser (1964) examined the effectiveness of diethylstilbestrol drop baits in reducing coyote reproduction, but did not examine any behavioral effects. Zemlicka (1995) found no effect of sterilization on courtship and territorial behaviors in captive coyotes.

Bromley (2000) demonstrated that packs of coyotes that had been surgically sterilized killed sheep significantly less often than packs of intact coyotes. However, for sterilization to be effective in modifying the predatory tendencies of coyotes and reducing predation on sheep, the behavioral components of coyote social ecology would need to remain unchanged (Asa 1995). This study examined the behavioral aspects of surgically sterilizing coyotes. Specifically, we addressed the following questions: $(i)$ will free-ranging sterilized coyotes differ from reproductive coyotes in terms of pair-bond maintenance? (ii) will members of a sterile pack remain together and maintain territory boundaries? (iii) will sterilization affect coyote pack size? (iv) will survival rates differ between sterile and intact coyotes? and $(v)$ will sterilization affect the residency rates of coyotes (i.e., the level of territory fidelity), or will sterile members leave packs that are not producing pups?

\section{Methods}

This study was conducted on $400 \mathrm{~km}^{2}$ of the Deseret Land and Livestock Ranch in northeastern Utah. The primary vegetation type is sagebrush steppe (Artimesia tridentata wyomingensis) with an understory of grasses, including needle and thread grass (Stipa comata), Indian rice grass (Oryzopsis hymenoides), and western wheatgrass (Pascopyrum smithii). Crested wheatgrass (Agropyrum desertorum) was planted on some areas of the ranch during the 1960s. Rocky outcrops and some irrigated meadow also make up a small portion of the ranch. The area receives approximately $27 \mathrm{~cm}$ of rainfall a year, and temperatures range from a winter average of $-9.5^{\circ} \mathrm{C}$ to a summer average of $15.6^{\circ} \mathrm{C}$. Most of the ranch is grazed by cattle each year.

During the spring and summer of 1997, coyotes were captured using padded leg-hold traps with tranquilizer tabs (Balser 1965). Traps were checked each morning and coyotes were weighed, aged by tooth wear (Gier 1968), ear-tagged, sexed, and fitted with radio transmitters (Advanced Telemetry Systems, Isanti, Minnesota). The purpose of capturing animals in the summer and spring of 1997 was to confirm that the coyote packs would kill sheep, as well as to allow for efficient capture of the pack with the aid of a helicopter by relocating radio-collared coyotes during winter. Collared and uncollared coyotes were captured using a helicopter and net gun (Barrett et al. 1982; Gese et al. 1987) during December 1997, January 1998, and January 1999. Packs were randomly divided into sham- and sterile-treatment groups. We captured and radio-collared as many members of each pack as possible. All captured coyotes were transported to a veterinary clinic for surgical sterilization. A premolar was extracted from each animal for aging by cementum annuli analysis (Linhart and Knowlton 1967). Females were sterilized by tubal ligation and males by vasectomy, leaving the hormonal system intact (Zemlicka 1995). Sham-treated animals underwent the same surgical procedure, but sterilization was not completed. All animals were held overnight for observation and released at the point of capture the following morning.

When sheep were present, from mid-May to September, coyotes were located once or twice daily from null telemetry stations or with a hand-held antenna (Mech 1983; White and Garrott 1990). Six null stations were placed on elevated points in an attempt to cover much of the study area; telemetry error was $\pm 1-2^{\circ}$ for the null stations. Coyotes were generally relocated during the time when most coyote movement and activity occurred (evening, night, and early morning). During the rest of the year, coyotes were located every 2 weeks, either from the ground or during the day from the air (Mech 1983). The software program LOCATE (Pacer, Truro, Nova Scotia) was used to calculate location coordinates, and CALHOME (Kie et al. 1996) was used to calculate adaptive kernel home-range estimators (Worton 1989). Minimum pack sizes were estimated from observations of coyote packs during aerial telemetry and reflect prewhelping (winter) pack sizes. To confirm the breeding status of the pack, searches were made by foot and from the air in all coyote territories to find dens and confirm the presence or absence of pups. Response to simulated howling was also used to monitor pup production (Harrington and Mech 1982).

Annual survival rates were calculated using MICROMORT (Heisey and Fuller 1985) by extrapolation of daily survival rates (Trent and Rongstad 1974). Rates were calculated for animals of known fate; these rates were compared with rates calculated assuming that all missing animals still lived, and assuming that they had all died 
Table 1. Half-weight association index scores for coyote dyads in sterile and shamoperated packs, Deseret Land and Livestock Ranch, Utah, 1998-1999.

\begin{tabular}{|c|c|c|c|c|}
\hline & \multicolumn{2}{|l|}{1998} & \multicolumn{2}{|l|}{1999} \\
\hline & Male-female & Male-male & Male-female & Male-male \\
\hline \multirow[t]{6}{*}{ Sterile packs } & 0.54 & 0.57 & 0.53 & 0.36 \\
\hline & 0.38 & 0.18 & 0.61 & 0.03 \\
\hline & 0.08 & 0.07 & 0.03 & 0.54 \\
\hline & 0 & 0.31 & 0.41 & \\
\hline & 0.06 & & 0.72 & \\
\hline & 0.07 & & 0.52 & \\
\hline \multirow[t]{3}{*}{ Sham-operated packs } & 0.14 & na & 0.16 & 0.08 \\
\hline & 0.20 & & 0.27 & 0.35 \\
\hline & & & & 0.12 \\
\hline
\end{tabular}

(Fuller 1989; Gese et al. 1989). The level of territory fidelity was examined by calculating residency rates in the same manner as survival rates but substituting dispersal for death in the calculation (Fuller 1989). A $z$ test was used to compare both survival and residency rates between sterile and sham-operated coyotes.

Bonds between all radio-collared pack members were analyzed by comparing the average distance between two animals located in the same hour with the distance between random locations for the same animals (Kitchen et al. 1999). A $t$ test was used to compare the mean distances of simultaneous $(<1 \mathrm{~h}$ apart) versus random locations. A half-weight association index (Brotherton et al. 1997) was also calculated:

$$
\frac{n}{n+1 / 2(x+y)}
$$

where $n$ is the number of times both animals were located together, $x$ is the number of times one animal was located without the other, and $y$ is the number of times the remaining animal was located without the $x$ animal. For animals that are always located together the index is 1 , and for animals that are never together it is 0 .

\section{Results}

From June 1997 to April 2000, 10 males and 9 females were sham-operated and 20 males and 6 females were sterilized and radio-collared; 3016 telemetry locations were collected. Two females and 1 male were initially captured and sham-operated in 1998, then recaptured and sterilized in the second year. In 1998, coyotes from 9 packs were radiocollared (5 packs of sterile coyotes and 4 packs of shamoperated coyotes). In 1999 and 2000, coyotes from 10 packs were radio-collared (4 packs of sterile coyotes and 6 packs of sham-operated coyotes). In three cases sterile animals were present in breeding packs, but they were associates rather than members of the breeding pair. We monitored members of 5 sterile and 4 intact packs during 1998, 6 sterile and 7 intact packs during 1999 (4 sterile and 3 intact packs were the same in 1998 and 1999), and 4 sterile and 6 intact packs through the 2000 breeding season (all 4 sterile and all 6 intact packs in 2000 were monitored previously in 1999).

\section{Pack affiliations and pair bonds}

Sterile coyotes maintained pair bonds similarly to shamoperated packs. The half-weight association index scores for 4 sterile breeding pairs were between 0.41 and 0.72 (Table 1). We did not have a comparable sample of sham- operated pairs, but these sterile pairs were located together, on average, $57 \%$ of the time. When we compared the halfweight association index scores for all dyads from sterile packs $(\bar{x}=0.313)$ with all dyads from sham-operated packs $(\bar{x}=0.19)$ summed over both years, there was no significant difference in the scores between all members of shamoperated and sterile packs $(t=1.32, P=0.198)$. In 1999 , sterile dyads $(\bar{x}=0.444)$ had a significantly higher score $(t=$ $2.45, P=0.031)$ than sham-operated dyads $(\bar{x}=0.199)$. This is probably due to a greater number of breeding pairs being captured and radio-collared in the sterile cohort and a greater number of nonbreeding associates being radio-collared in the sham-operated cohort.

The average distance between members of a sterile breeding pair located within the same hour was $0.47 \mathrm{~km}(n=4$ pairs; Table 2). In Colorado, Kitchen et al. (1999) calculated an average distance of $1.07 \mathrm{~km}$ between members of the same pack. Breeding members of sterile packs were significantly $(t=-10.17, P<0.0001)$ closer to each other than would be expected from random locations $(\bar{x}=2.06 \mathrm{~km}$ apart). In 1998, when the distances for all dyads from sterile packs are compared with random locations, the difference is not significant $(t=-1.68, P=0.11)$. This is probably due to the small number of locations available for each animal (mean 15.5), and 6 of the 10 dyads were from comparisons of distances between members of 1 large pack. When the distances for all dyads from sterile packs for 1999 are compared with random locations (mean points/animal $=121)$, the dyads are significantly closer than would be expected $(t=$ $-2.70, P=0.016)$. In 1999 , all dyads from sham-operated packs were also closer than expected when compared with random locations $(t=-3.03, P=0.016)$. The composition of sterile coyote packs persisted over several years, and was similar to relations among individuals in intact packs.

\section{Home-range size and overlap}

The density of coyotes in the study area was fairly high, and all available territories were filled (i.e., evidence such as scats and tracks was present even in areas where coyotes were not radio-collared). The mean territory size $(90 \%$ isopleth) for sterile packs was $17.4 \mathrm{~km}^{2}(n=5)$, while territories of sham-operated packs $(n=6)$ averaged $16.8 \mathrm{~km}^{2}$ (Fig. 1); there was no significant difference $(t=-0.196, P=$ 0.85 ) between territory sizes of sterile and sham-operated packs. Average overlap between coyote territories drawn to the $95 \%$ isopleth was $21 \%$ (range $0-39 \%$ ). The core areas 
Table 2. Distances $(\mathrm{km})$ between members of social dyads in sterile and sham-operated coyote packs when located in the same hour, compared with random pairs of locations, Deseret Land and Livestock Ranch, Utah, 1998-1999.

\begin{tabular}{|c|c|c|c|c|}
\hline & \multicolumn{2}{|c|}{ Male-female } & \multicolumn{2}{|l|}{ Male-male } \\
\hline & Concurrent & Random & Concurrent & Random \\
\hline \multirow[t]{12}{*}{ Sterile pack } & 0.584 & 2.195 & 0.574 & 2.030 \\
\hline & 0.424 & 2.327 & 3.324 & 3.429 \\
\hline & 3.494 & 3.677 & 0.399 & 2.189 \\
\hline & 0.652 & 1.733 & 0.383 & 1.438 \\
\hline & 0.222 & 2.112 & 0.949 & 1.485 \\
\hline & 0.373 & 2.203 & 0.212 & 2.300 \\
\hline & 0.563 & 1.624 & 0.776 & 1.838 \\
\hline & 0.185 & 0.842 & & \\
\hline & 2.902 & 3.530 & & \\
\hline & 2.761 & 2.718 & & \\
\hline & 2.757 & 3.065 & & \\
\hline & 2.082 & 2.166 & & \\
\hline \multirow[t]{4}{*}{ Sham-operated pack } & 2.117 & 3.019 & 1.303 & 1.638 \\
\hline & 1.190 & 2.822 & 0.919 & 2.278 \\
\hline & 1.258 & 1.421 & 1.912 & 3.164 \\
\hline & 1.401 & 2.538 & & \\
\hline
\end{tabular}

(estimated at the $60 \%$ isopleth) between 2 packs overlapped only once: $3 \%$ between two packs. There was no significant difference between the average overlap of 2 adjacent sterile packs and the overlap of a sterile pack with an adjacent sham-operated pack $(t=0.19, P=0.85)$. Nor was the average overlap between 2 adjacent sterile packs significantly different from that between 2 adjacent sham-operated packs $(t=-0.01, P=0.91)$.

\section{Territory fidelity}

In 1998 there was no significant difference between the annual residency rate of sham-operated and sterile coyotes $(z=0.86, P=0.195)$. Sham-operated coyotes remained in territories at an annual rate of 0.88 ( 1 coyote dispersed) and sterile coyotes at a rate of 0.74 (3 coyotes dispersed); in calculating rates, animals of unknown fate were censored. In 1999 , only 1 sterile male coyote is known to have dispersed from its territory. In 2000 there were no confirmed dispersals of coyotes in either treatment group from their territory. Thus, sterile coyotes remained within their territory at similar rates to members of reproductive packs. The lack of reproduction in the sterile packs did not increase abandonment of the territory, even after 3 breeding seasons.

\section{Pack size}

Our purpose in using sterilization was to modify the predatory behavior of coyotes by reducing the motivation of provisioning pups. However, because sterilization could affect pack size, we compared minimum observed pack sizes between sham-operated and sterile coyote packs. This minimum count represents prewhelping (winter) pack size. In 1998 the mean size of sterile and sham-operated packs was 2.8 and 3.0, respectively $(t=-0.25, P=0.80)$. In 1999 the mean size of sterile and sham-operated packs was 2.2 and 3.4 coyotes, respectively $(t=-1.42, P=0.18)$. In 2000 the average size of the sham-operated packs was 3.0 coyotes and that of the sterile packs was 2.4 coyotes $(t=-1.04, P=$ 0.32 ). Thus, over 3 years there was no appreciable effect of sterilization on the number of coyotes in each pack observed in winter. We emphasize that these pack-size estimates are from winter, after most dispersal of young has occurred. Pups were produced in the intact packs, but these pups had either dispersed or died by the next breeding season (January), hence the size of the core social unit remained unchanged between reproductive and non-reproductive packs.

\section{Survival}

Forty-two coyotes were radio-collared and monitored for 22167 radio-days over the course of the study; 20 coyotes were alive and accounted for at the end of the study. Nine coyotes were known to have died during the course of the study: 4 died of unknown causes and 5 were shot (usually outside the study area). Survival rates calculated when missing animals were censored versus rates calculated assuming that missing animals had died and then assuming that they still lived were not significantly different $(z=0.116, P=$ 0.45). In 1998, the annual survival rate for sham-operated and sterile coyotes was 0.57 and 0.91 , respectively $(z=2.06$, $P=0.02)$. In 1999, sterile and sham-operated coyotes had an annual survival rate of 0.91 and 0.60 , respectively $(z=1.36$, $P=0.09$ ). In 2000 (January-April), sham-operated coyotes had a higher survival rate (1.00) than sterile coyotes $(0.89)$ $(z=1.56, P=0.03)$.

\section{Discussion}

A major concern when contraceptive intervention is used with canids is the effects on behavior and social structure (Asa 1995). Our results indicate that surgical sterilization had no effect on pair-bond maintenance and territorial behavior among free-ranging coyotes. Sterile packs of coyotes remained together, in the same territory, even after no pups had been produced for 3 years. This observation of no behavioral change is supported by the results of other studies of sterile carnivores. Zemlicka (1995), working with captive coyotes, observed that sterile coyotes displayed all social 
Fig. 1. Territories (90\% isopleth) of sham-operated and sterile coyote packs, Deseret Land and Livestock Ranch, Utah, 1999.

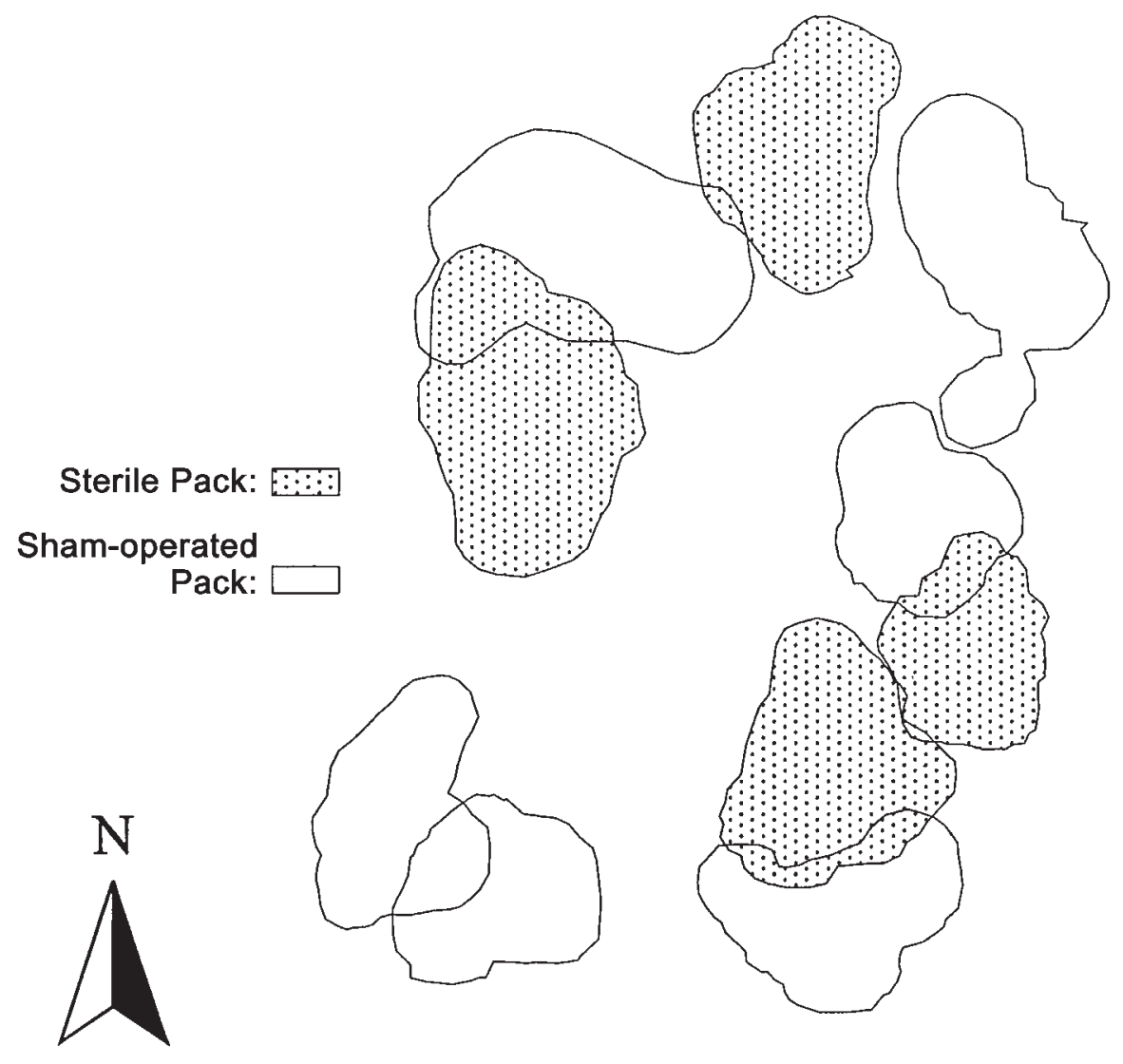

$10 \mathrm{~km}$

behaviors similarly to intact animals. In Minnesota, Mech et al. (1996) vasectomized 5 free-ranging wolves and found that all of them stayed in their respective territories after sterilization, although 1 male dispersed after 2 years and formed a new pair bond in another pack. One vasectomized wolf remained in his territory for 7 years before he was killed. In another study, a contraceptive implant (melengesterol acetate) was administered to 10 free-ranging female lions (Panthera leo) (Orford and Perrin 1988). The treated lionesses produced no cubs but remained as members of their prides, and no behavioral changes were noted. Red fox vixens have also been surgically sterilized, with no evidence of changes in their social behavior, dominance relationships, or survival (Bubela 1999).

Territory overlap for sterile coyote packs was similar to that for sham-operated packs, and associate animals stayed with the pack. We also found no significant difference between the sizes of territories occupied by sterile and shamoperated packs. Red fox vixens that had been surgically sterilized maintained home ranges similar in size to those of intact females; however, home-range overlap increased among sterile females (Saunders and McIlroy 1996). Since our surgical-sterilization method (vasectomy and tubal ligation) left all hormonal systems intact (Zemlicka 1995), the results may not be the same if spaying and castration (in which reproductive systems are removed) are employed. Modification of hormonal systems (e.g., castration) could have a negative effect on behavior (Asa 1995). Territorial defense, aggression, pair-bond formation, and scent-marking behavior appear to be hormone-dependent (Asa et al. 1990; Asa 1995). Therefore, the method of sterilization used should leave the hormone systems intact.

While our principal aim in sterilizing the coyotes was to modify their predatory behavior, a concern with sterilization is that it may affect population size. Although we did not study the long-term population effects of sterilization, during the 3 years (1998-2000) of aerial telemetry and observation in winter, prewhelping (winter) pack sizes did not differ between sham-operated and sterile coyote packs. We emphasize that pup production was confirmed in the intact packs, but loss of pups due to either dispersal or death reduced these intact packs to levels similar to those of sterile packs by the following winter. Thus, since territory size and pack size were unchanged, the winter density of coyotes in the study area was not reduced. If "problem" animals in individual packs are closely targeted for sterilization, then any longterm population effect should be minimal. Applying sterilization on a larger scale may affect a population, but this remains untested.

Because we sterilized as many pack members as possible, we have no data on whether nonsterile associates would reproduce, or replace sterile alpha coyotes. It is important that 
the breeding pair be identified and targeted if possible, which can prove difficult, particularly in areas where coyote packs are large. During our study we captured as many coyotes as possible from each pack and treated all members accordingly in the attempt to stop pup production (i.e., the sample unit in our study was the social group or pack). In research with red foxes (Bubela 1999), where only the dominant vixen was sterilized, none of the 3 vixens was replaced in the first year. In the second year, 1 sterile dominant female was replaced by her sister.

Sterile coyotes had a significantly higher annual survival rate than reproductive animals in 2 of the 3 years. Sterile animals did not incur reproductive costs, but since there was no significant difference between survival rates of males $(0.78)$ versus females $(0.52)$ (for 2 years, $z=-1.03, P=0.15$ ), this may not explain the difference in survival rates. Our results may have been confounded by the number of coyotes that were shot. Coyotes were most often shot when off the study area (shooting was prohibited in the study area), and some of the "missing" coyotes were probably also shot. However, our survival rates are similar to those reported for mostly unexploited coyote populations. Gese et al. (1989) studied a relatively unexploited population in southeastern Colorado and reported annual survival rates of 0.72-0.80, while Andelt (1985) reported an annual adult survival rate of 0.68 in south Texas.

Territory fidelity, as measured by residency rates, did not differ significantly between the two treatment groups. The sterile animals appeared to be more likely to disperse than the sham-operated animals, but the sample size was small (5). Intuitively, fewer internal pressures or stresses in the absence of pup recruitment should lessen the need for other pack members to disperse (Gese et al. 1996), but our findings do not support this assumption. Associates may gain advantages by staying, particularly in areas where larger pack size may facilitate the killing and defense of larger prey (Bekoff and Wells 1986; Gese et al. 1996). Our dispersal rates for adults were similar to those reported in the literature (Gese et al. 1989) for an unexploited coyote population. We only examined residency rates for adult coyotes. Because we did not radio-collar pups or juvenile coyotes, and capture efforts were made during December and January (after the main pulse of dispersal would have occurred), we were unable to estimate dispersal rates. If we had radiocollared pups in the fall, then dispersal could have been measured in the intact packs but not in the sterile packs.

Attempts to limit coyote predation on sheep often involve removing as many coyotes as possible. This type of nonspecific control often has limited effectiveness (Conner et al. 1998). Not all coyotes kill sheep (Sacks et al. 1999; Bromley 2000) and most killing is performed by the breeding pair (Sacks et al. 1999). Thus, the removal of coyotes that are not actually killing sheep could be counterproductive, opening territories to other potential sheep-killing coyotes. Bromley (2000) demonstrated that sterile coyote packs killed fewer sheep than packs with pups. Provisioning of pups appears to be a major motivation for coyotes to kill more larger, more profitable prey (Till and Knowlton 1983). Because packs of sterile coyotes maintained pair bonds and territories, and had higher survival rates in 2 of 3 years, a sterile coyote pair could prove to be a viable management tool to reduce coyote predation on sheep. Coyotes are long-lived and highly territorial (Knowlton et al. 1999), thus a sterile pair could exclude other potentially sheep-killing coyotes for several years if the sterile coyotes are allowed to survive. Sterilization could also prove an effective management tool where lethal control is not a socially acceptable option. Sterilization may be more acceptable to the public (Arthur 1981; Cluff and Murray 1995; Mech et al. 1996) than lethal control methods such as aerial hunting or trapping. Although our method of sterilization may appear to be costly ( $\$ 560$ per coyote), an alternative chemical sterilant (DeLiberto et al. 1998) that does not affect the hormonal system (Asa 1995) and could be delivered effectively and economically may be an efficient method to sterilize coyotes and modify their predatory behavior while leaving social behaviors intact.

\section{Acknowledgements}

We thank Todd Chaudhry, Kristen Duran, Randy Farrar, Laurel Kellogg, Laura Kemp, Holly Smith, Justin Stevenson, Michael Wichrowski, Pam Wilmot, and Ana Margarita WocColburn for field assistance; Amy Barras, Tom DeLiberto, Terry Hall, Amy Seglund, Doris Zemlicka, and the staff at the Bear River Veterinary Clinic, Evanston, Wyoming, for assistance with surgical sterilization of coyotes; Fred Knowlton for discussions on study design; Joe Anderson, Gary Brennan, Carl Meyer, and Tim Milliken of Hawkins and Powers Aviation for helicopter flying and aerial net-gunning; Rick Danvir and Bill Hopkin of Deseret Land and Livestock for logistical assistance and access to the ranch; Glen Gantz for aerial telemetry; and John Bissonette, Fred Provenza, L. David Mech, Russ Mason, Michael Fall, and an anonymous reviewer for reviews of the manuscript. This study was funded and supported by the National Wildlife Research Center, Logan Field Station, and the Utah Agricultural Experiment Station at Utah State University. Procedures for coyote capture, handling, immobilization, and surgical sterilization, and sheep husbandry were reviewed and approved by Institutional and Animal Care and Use Committees at the National Wildlife Research Center and Utah State University.

\section{References}

Andelt, W.F. 1985. Behavioral ecology of coyotes in south Texas. Wildl. Monogr. No. 94. pp. 1-45.

Arthur, L.M. 1981. Coyote control: the public response. J. Range Manag. 34: 14-15.

Asa, C.S. 1995. Physiological and social aspects of reproduction of the wolf and their implications for contraception. In Ecology and conservation of wolves in a changing world. Edited by L.N. Carbyn, S.H. Fritts, and D.R. Seip. Occas. Publ. No. 35, Canadian Circumpolar Institute, University of Alberta, Edmonton. pp. 283-286.

Asa, C.S., Mech, L.D., Seal, U.S., and Plotka, E.D. 1990. The influence of social and endocrine factors on urine-marking by captive wolves (Canis lupus). Horm. Behav. 24: 497-509.

Balser, D.S. 1964. Management of predator populations with antifertility agents. J. Wildl. Manag. 28: 352-358.

Balser, D.S. 1965. Tranquilizer tabs for capturing wild carnivores. J. Wildl. Manag. 29: 438-442.

Barrett, M.W., Nolan, J.W., and Roy, L.D. 1982. Evaluation of a hand-held net-gun to capture large mammals. Wildl. Soc. Bull. 10: $108-114$. 
Bekoff, M., and Wells, M.C. 1986. Social ecology and behavior of coyotes. Adv. Study Behav. 16: 251-338.

Bromley, C. 2000. Coyote sterilization as a method of reducing depredations on domestic lambs. M.S. thesis, Utah State University, Logan.

Brotherton, P.N.M., Pemberton, J.M., Komers, P.E., and Malarky, G. 1997. Genetic and behavioural evidence of monogamy in a mammal, Kirk's dik-dik (Madoqua kirkii). Proc. R. Soc. Lond. B Biol. Sci. 264: 675-681.

Bubela, T.M. 1999. Social effects of sterilizing free-ranging red foxes in subalpine Australia. Ph.D. dissertation, University of Sydney, Sydney, Australia.

Cluff, H.D., and Murray, D.L. 1995. Review of wolf control methods in North America. In Ecology and conservation of wolves in a changing world. Edited by L.N. Carbyn, S.H. Fritts, and D.R. Seip. Occas. Publ. No. 35, Canadian Circumpolar Institute, University of Alberta, Edmonton. pp. 491-504.

Conner, M.M., Jaeger, M.M., Weller, T.J., and McCullough, D.R. 1998. Effect of coyote removal on sheep depredation in northern California. J. Wildl. Manag. 62: 690-699.

Converse, K.A., and Kennelly, J.J. 1994. Evaluation of Canada goose sterilization for population control. Wildl. Soc. Bull. 22: 265-269.

DeLiberto, T.J., Gese, E.M., Knowlton, F.F., Mason, J.R., Conover, M.R., Miller, L., Schmidt, R.H., and Holland, M.K. 1998. Fertility control in coyotes: is it a potential management tool? In Proceedings of the 18th Vertebrate Pest Conference, Costa Mesa, California, March 2-5, 1998. Edited by R.O. Baker and A.C. Crabb. University of California, Davis. pp. 144-149.

Fuller, T.K. 1989. Population dynamics of wolves in north-central Minnesota. Wildl. Monogr. No. 105. pp. 1-41.

Garrott, R.A. 1995. Effective management of free-ranging ungulate populations using contraception. Wildl. Soc. Bull. 23: 445-452.

Gee, C.K., Magleby, R.S., Nielson, D.B., and Stevens, D.M. 1977. Factors in the decline of the western sheep industry. Agricultural Economics Rep. No. 377, Economics Research Service, U.S. Department of Agriculture, Washington, D.C.

Gese, E.M., Rongstad, O.J., and Mytton, W.R. 1987. Manual and net-gun capture of coyotes from helicopters. Wildl. Soc. Bull. 15: 444-445.

Gese, E.M., Rongstad, O.J., and Mytton, W.R. 1989. Population dynamics of coyotes in southeastern Colorado. J. Wildl. Manag. 53: $174-181$.

Gese, E.M., Ruff, R.L., and Crabtree, R.L. 1996. Social and nutritional factors influencing the dispersal of resident coyotes. Anim. Behav. 52: 1025-1043.

Gier, H.T. 1968. Coyotes in Kansas. Kans. State Coll. Agric. Exp. Stn. Bull. No. 393.

Haight, R.G., and Mech, L.D. 1997. Computer simulation of vasectomy for wolf control. J. Wildl. Manag. 61: 1023-1031.

Harrington, F.H., and Mech, L.D. 1982. An analysis of howling response parameters useful for wolf pack censusing. J. Wildl. Manag. 46: 686-693.

Heisey, D.M., and Fuller, T.K. 1985. Evaluation of survival and cause-specific mortality rates using telemetry data. J. Wildl. Manag. 49: 668-674.

Kie, J.G., Baldwin, J.A., and Evars, C.J. 1996. Calhome: a program for estimating animal home ranges. Wildl. Soc. Bull. 24: 342-344.

Kirkpatrick, J.F., Liu, I.K.M., and Turner, J.W., Jr. 1990. Remotely- delivered immunocontraception in feral horses. Wildl. Soc. Bull. 18: $326-330$.

Kitchen, A.M., Gese, E.M., and Schauster, E.R. 1999. Resource partitioning between coyotes and swift foxes: space, time, and diet. Can. J. Zool. 77: 1645-1656.

Knowlton, F.F., Gese, E.M., and Jaeger, M.M. 1999. Coyote depredation control: an interface between biology and management. J. Range Manag. 52: 398-412.

Linhart, S.B., and Enders, R.K. 1964. Some effects of diethylstilbestrol in reproduction in captive red foxes. J. Wildl. Manag. 28: $358-363$.

Linhart, S.B., and Knowlton, F.F. 1967. Determining age of coyotes by tooth cementum layers. J. Wildl. Manag. 31: 362-365.

Matschke, G.H. 1977. Microencapsulated diethylstilbestrol as an oral contraceptive in the white-tailed deer. J. Wildl. Manag. 41: 87-91.

Mech, L.D. 1983. Handbook of animal radio tracking. University of Minnesota Press, Minneapolis.

Mech, L.D., and Fritts, S.H. 1993. Vasectomized wolves maintain territory. U.S. Dep. Inter. Fish Wildl. Serv. Res. Inf. Bull. No. 24.

Mech, L.D., Fritts, S.H., and Nelson, M.E. 1996. Wolf management in the 21 st century: from public input to sterilization. J. Wildl. Res. 1: 195-198.

Oleyar, C.M., and McGinnes, B.S. 1974. Field evaluation of diethylstilbestrol for suppressing reproduction in foxes. J. Wildl. Manag. 38: 101-106.

Orford, H.J.L., and Perrin, R.M. 1988. Contraception, reproduction and demography of free-ranging Etosha lions. J. Zool. (Lond.), 216: 717-733.

Pech, R., Hood, G.M., McIlroy, J., and Saunders, G. 1997. Can foxes be controlled by reducing their fertility? Reprod. Fertil. Dev. 9: 41-50.

Plotka, E.D., and Seal, U.S. 1989. Fertility control in female whitetailed deer. J. Wildl. Dis. 25: 643-646.

Sacks, B.N., Jaeger, M.M., Neale, J.C.C., and McCullough, D.R. 1999. Territoriality and breeding status of coyotes relative to sheep predation. J. Wildl. Manag. 63: 593-605.

Saunders, G., and McIlroy, J. 1996. The effect of imposed sterility on the survival, fecundity, territoriality and social structure of foxes. In Abstracts from the 4th International Conference on Fertility Control for Wildlife Management, Great Keppel Island, Queensland, Australia, July 8-11, 1996. [Abstr.]

Till, J.A., and Knowlton, F.F. 1983. Efficacy of denning in alleviating coyote depredations upon domestic sheep. J. Wildl. Manag. 47: 1018-1025.

Trent, T.T., and Rongstad, O.J. 1974. Home range and survival of cottontail rabbits in southwestern Wisconsin. J. Wildl. Manag. 38: 459-472.

Turner, J.W., Liu, I.K.M., and Kirkpatrick, J.F. 1996. Remotely delivered immunocontraception in free roaming burros. J. Reprod. Fertil. 107: 31-35.

U.S. Department of Agriculture. 1998. Utah Sheep Report, 1998. National Agricultural Statistics Service, Agricultural Statistics Board, Washington, D.C.

White, G.C., and Garrott, R.A. 1990. Analysis of wildlife radiotracking data. Academic Press, Inc., New York.

Worton, B.J. 1989. Kernel methods for estimating the utilization distribution of home range studies. Ecology, 70: 164-168.

Zemlicka, D.E. 1995. Seasonal variation in the behavior of sterile and nonsterile coyotes. M.S. thesis, Utah State University, Logan. 
Copyright $\odot 2003$ EBSCO Publishing 